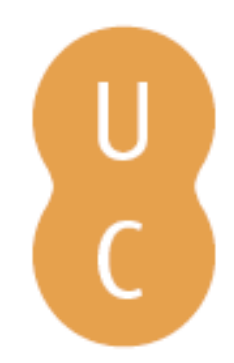

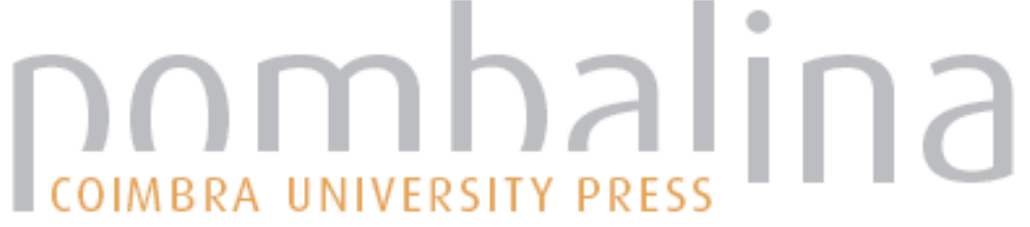

Occupational choice factor and professional future perspective in early adulthood

Autor(es): $\quad$ Petrash, Marina D.; Strizhitskaya, Olga Y.

Publicado por: Imprensa da Universidade de Coimbra

URL

persistente: URI:http://hdl.handle.net/10316.2/38623

DOI: $\quad$ DOI:http://dx.doi.org/10.14195/978-989-26-0775-7_19

Accessed : $\quad$ 26-Apr-2023 12:52:39

A navegação consulta e descarregamento dos títulos inseridos nas Bibliotecas Digitais UC Digitalis, UC Pombalina e UC Impactum, pressupõem a aceitação plena e sem reservas dos Termos e Condições de Uso destas Bibliotecas Digitais, disponíveis em https://digitalis.uc.pt/pt-pt/termos.

Conforme exposto nos referidos Termos e Condições de Uso, o descarregamento de títulos de acesso restrito requer uma licença válida de autorização devendo o utilizador aceder ao(s) documento(s) a partir de um endereço de IP da instituição detentora da supramencionada licença.

Ao utilizador é apenas permitido o descarregamento para uso pessoal, pelo que o emprego do(s) título(s) descarregado(s) para outro fim, designadamente comercial, carece de autorização do respetivo autor ou editor da obra.

Na medida em que todas as obras da UC Digitalis se encontram protegidas pelo Código do Direito de Autor e Direitos Conexos e demais legislação aplicável, toda a cópia, parcial ou total, deste documento, nos casos em que é legalmente admitida, deverá conter ou fazer-se acompanhar por este aviso. 


\section{INTERNATIONAL \\ STUDIES IN TIME \\ PERSPECTIVE}

MARIA PAULA PAIXÃO

JOSÉ TOMÁS DA SILVA

(COORD.)

VICTOR ORTUÑO

PEDRO CORDEIRO

(EDITORS)

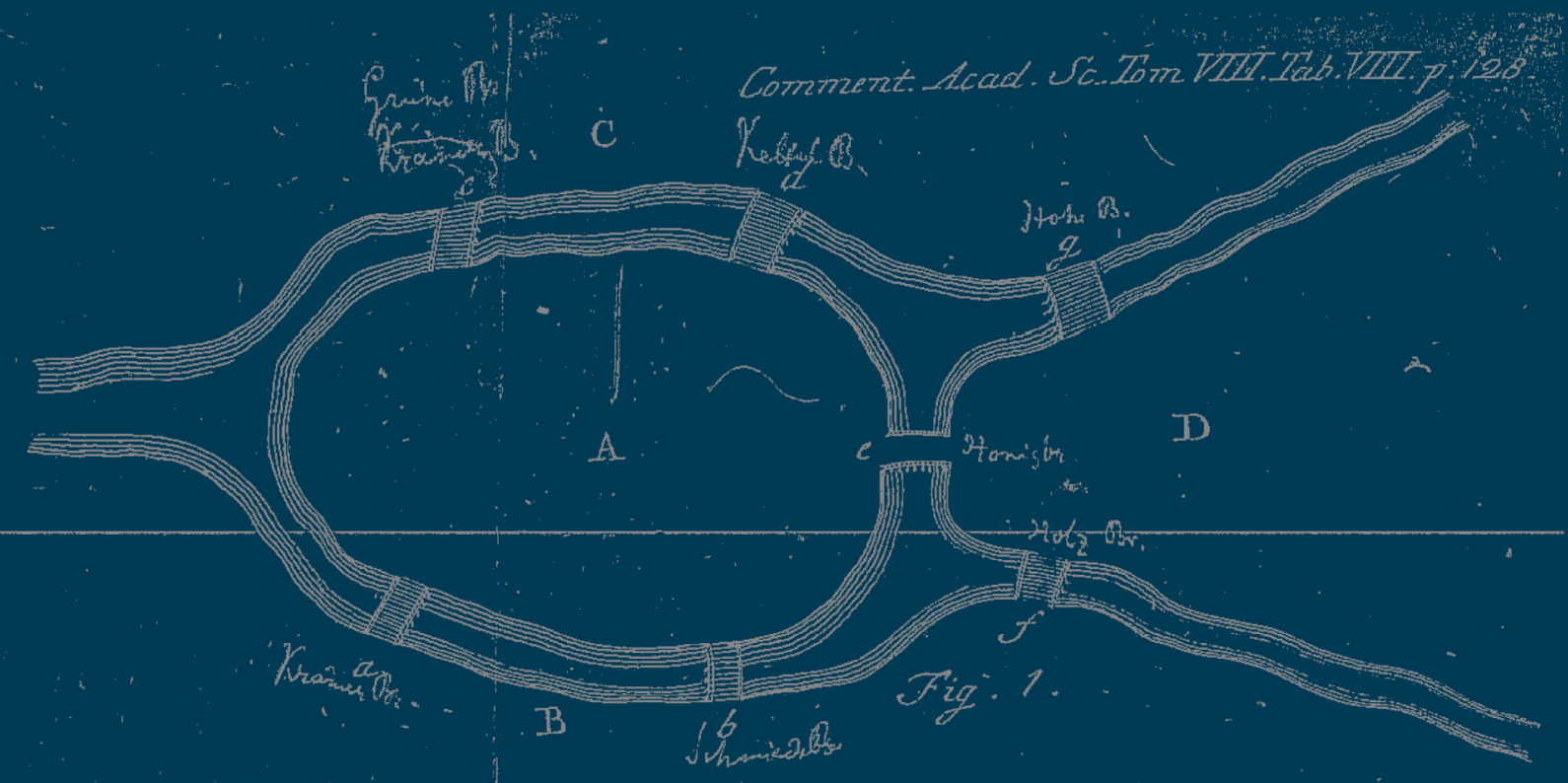

IMPRENSA DA

UNIVERSIDADE

DE COIMBRA

COIMBRA

UNIVERSITY

PRESS 


\title{
Chapter 19 \\ OCCUPATIONAL CHOICE FACTOR AND PROFESSIONAL FUTURE PERSPECTIVE IN EARLY ADULTHOOD
}

\author{
Marina D. Petrash \\ Olga Y. Strizhitskaya \\ Saint Petersburg State University, Faculty of Psychology, Russian Federation \\ mp.07@bk.ru \\ olga_stri@hotmail.com
}

\begin{abstract}
Aвstract: This research is devoted to the formation of professional future emotional position in professional development among young adults. The study considers the relationship between occupational choice factor, emotional position to professional future and professional development factors. Participants $(\mathrm{N}=179)$ were divided into two groups: students (M. age $=19, \mathrm{SD}=1.3$ ), young professionals $(M$. age $=25.4, S D=2.4$ ). Emotional position to professional future was measured with the M.Gynzburg questionnaire, including six scales: fear, anxiety, indifference, optimism, confidence, interest. The occupational choice factor included two special questions: 1) awareness of choice; 2) correctness of choice. Six professional development factors were measured by special questions: the professional development factors: "Contentment of a professional life" and "Professional Self-realization"; four professional activity factors: "Psycho-physiological recover", "Dedication", "Self-control of behavior", and "Interpersonal communication". Correlation analysis proved that the occupational choice factor correlates with emotional position to professional future and all professional development factors. The correct choice and negative modalities of emotional position to professional future were negatively and significantly correlated $(p \leq 0.001)$. The correct and aware choice, positive emotional position modalities and all factors of professional development were positively correlated $(p \leq 0.01 ; p \leq 0.001)$. The correct and aware choice was determined to be the most relevant predictor of positive position to professional future and constructive professional development.
\end{abstract}

Keywords: occupational choice, emotional position, professional future, professional development, predictor of positive attitude

\section{INTRODUCTION}

Professional self-determination based on a professional choice, professional orientation, which is of interest to the profession, and a leaning towards it allow the student to acquire the behaviors and qualities necessary in a particular person. The period of early adulthood involves three important stages in the professional development of a personality: learning in a professional college; entry into the profession and entry into the profession as a colleague.

After graduating from high school, the process of entering a profession begins. A young specialist masters the skills of his work and starts to improve his professional skills. When problems occur at the stage of entering the profession, the young person is not yet analyzing 
whether or not his occupational choice was made correctly. It is crisis experiences that make him think about it, though it does not always happen to everyone (Petrash, 2011).

Our study was conducted to examine the relationship between factors of professional choice and emotional position to professional future in the context of the current situation of professional development for students and young professionals.

In accordance with the purpose of the study, tasks were aimed at exploring professional self-determination in choosing a profession, personal characteristics, satisfaction with professional development, and the study of coping strategies. We decided that the listed characteristics may serve as predictors of emotional attitude to professional future.

\section{METHOD}

Emotional attitude to professional future was measured with the M.Gynzburg questionnaire, including six scales: fear, anxiety, indifference, optimism, confidence, interest.

The occupational choice factor included two special questions: 1) awareness of choice; 2) correctness of a choice. A first question of the factors of the professional choice included three answer choices: a) chose profession carefully weighing their aspirations, abilities and personality characteristics; b) were not serious about a career in something; c) undefined. Answers to the second question: (a) fully confident; b) can't give a definitive answer; 3) I was sure that my choice was wrong.

Six professional development factors were measured by special questionnaires: the professional development factors: "Contentment of a professional life" and "Professional Self-realization"; four professional activity factors: "Psycho-physiological recover", "Dedication", "Self-control of behavior", and "Interpersonal communication" (Petrash, 2008).

Personal characteristics were studied using a Big five personality test questionnaire. Coping strategies were measured by Ways of Coping Questionnaire.

\section{Participants}

All participants $(\mathrm{N}=179)$ were divided into two groups: students (M. age=19, $\mathrm{SD}=1.3)$, young professionals (M. age $=25.4, \mathrm{SD}=2.4$ ).

\section{Statistical analysis}

The software SPSS 17.0 for Windows was used to input and analyze the data.

\section{RESULTS}

\section{Occupational choice factor}

All 179 young people were asked to evaluate their professional choices, attitude to their professional future, contentment with professional life, personality characteristics and coping strategies. Using cluster analysis, we identified the group with a different assessment 
of their professional choices: survey questions: "how seriously did you come to the choice of a profession" and "score choice" (table 1).

Table 1 - Groups with different assessment of their professional choices

\begin{tabular}{|l|l|l|}
\hline \multicolumn{1}{|c|}{1 cluster } & 2 cluster & 3 cluster \\
\hline $\begin{array}{l}\text { - frivolous approach to choice of } \\
\text { profession } \\
\text { - view incorrect } \\
\text { - low score for yourself as a subject } \\
\text { of professional activity. }\end{array}$ & $\begin{array}{l}\text { - serious approach to the choice } \\
\text { of profession } \\
\text { - confident in choosing } \\
\text { - high score for yourself as a } \\
\text { subject of professional activity }\end{array}$ & $\begin{array}{l}\text { - doubts about the correctness and } \\
\text { awareness } \\
\text { average rating for yourself as the } \\
\text { subject of professional activity }\end{array}$ \\
\hline
\end{tabular}

\section{Occupational choice factor and professional future}

For the students of the second and third clusters a predominance of positive modalities (interest, confidence and optimism) was revealed in relation to the professional future. Students of the first cluster with indifference had anxiety and fear in relation to their professional future.

The occupational choice factors were negatively related to scores on Gynzburg's scale of "indifference" $(r=-0.373, p=0.000)$. On the other hand, awareness of a choice and correctness of a choice had a positive correlation with the positive relation to the professional future: $r=0.496, p=0.000$ (table 2).

For all clusters of young professionals a predominance of positive modalities was revealed (interest, confidence and optimism) in relation to their professional future. A negative attitude to professional future (fear, anxiety, indifference) negatively correlated with the factor of occupational choice: "correctness of a choice" $(r=-0.281, p=0.006$; $r=-0.288, p=0.005$ and $r=-0.212, p=0.040$ accordingly). "Awareness of choice" and "correctness of choice" related positively to scores on Gynzburg's scale of "confidence" and “interest" ( $r=0.255, p=0.013 ; r=0.270, p=0.008$ accordingly).

Table 2 - Scores of Gynzburg's scale (for the group of students)

\begin{tabular}{|l|c|c|c|c|c|c|c|c|}
\hline & \multicolumn{2}{|c|}{1 cluster } & \multicolumn{2}{c|}{2 cluster } & \multicolumn{2}{c|}{3 cluster } & \multirow{2}{*}{$\mathrm{F}$} & \multirow{2}{*}{$p$} \\
\hline Fear & $\mathrm{m}$ & $\sigma$ & $\mathrm{m}$ & $\sigma$ & $\mathrm{m}$ & $\sigma$ & & \\
\hline Anxiety & 7 & 1.9 & 5 & 1.9 & 5.4 & 1.7 & 3.570026 & 0.033 \\
\hline Indifference & 8.6 & 2.8 & 6.8 & 2.9 & 7.7 & 1.9 & & \\
\hline Interest & 7.6 & 4.9 & 4.4 & 1.9 & 5.1 & 2.4 & 9.283892 & 0.000 \\
\hline Confindence & 6.3 & 2 & 12.2 & 1.5 & 12.2 & 1.9 & 22.98761 & 0.000 \\
\hline Optimism & 6.1 & 2.5 & 12.3 & 1.8 & 11 & 1.9 & 30.69216 & 0.000 \\
\hline
\end{tabular}




\section{Current situation of professional development}

In the first cluster, as students and beginning professionals, the current situation of professional development was unfavorable. More respondents were identified as having low values of satisfaction with the profession $(98 \%$ of students and $54 \%$ of young professionals) and a low desire for professional self-realization (85\% of students and 36\% of young professionals). The second cluster indicators of professional development were in the range of high values.

\section{Coping strategies}

The study of coping behavior of students, showed that the first cluster is dominated by strategy: Accepting Responsibility, Escape-Avoidance, Distancing, Self-Controlling, Confrontive Coping. In the third and second clusters: Planful Problem Solving, Positive Reappraisal. Young professionals of the first cluster used Confrontive Coping, while the subjects of the second and third clusters used a strategy of Planful Problem Solving.

\section{Personal characteristics, occupational choice factors and emotional position to the professional future}

For a group of students the occupational choice factors ("awareness of choice" and "correctness of choice") were negatively related to the personal characteristic of "Emotional Stability" ( $r=-0.232, p=0.033$; and $r=-0.348, p=0.001$ accordingly). A comparative analysis indicated a "low" level of "Emotional Stability" for students in the first cluster.

The personal characteristic of "Extraversion" had a negative correlation with the factor of occupational choice: "correctness of choice" $(r=-0.215, p=0.037)$. A personal characteristic of "Emotional Stability" related positively to scores on Gynzburg's scale of "anxiety" $(r=0.263, p=0.010)$.

\section{Discussion}

The study revealed that the fact of "premeditated choice" of occupation favors constructive evaluation of their professional development; increases positive modalities in relation to their professional future, and reduces fear and indifferent attitudes. Each stage of professional formation is determined by its content.

Using regression analysis, we have shown that predictors of the positive attitude to professional future among students are factors of occupation choice; contentment with professional life, self-realization in the profession, interpersonal communication, and self-control of behavior; personal characteristics: affection, coping strategies: positive reappraisal, planning, problem solving and responsibility.

Self-realization in the profession, Psycho-physiological recover, interpersonal communication; personal characteristics: attachment and extraversion, and coping-strategy plan- 
ning solutions selected are characteristics which are predictors of a positive attitude to the professional future of young professionals.

Our other results showed that low values of satisfaction with the profession, low desire for professional self-realization; predominance of negative modalities (fear, anxiety, indifference) to professional future and coping strategies: Accepting Responsibility, EscapeAvoidance, Distancing, Self-Controlling, Confrontive Coping of early adulthood, could be linked with professional turning points.

\section{Conclusions}

1. The awareness and correctness of the occupational choice factor may have a positive impact on the professional future and relevant measures should be taken to reduce the experience of professional turning points.

2. Both professional future esteem and evaluation of the current career situation depend on the motivational involvement of a person in the process of professional self-determination while making an occupational choice ("premeditated choice").

3. The correct and aware choice was determined to be the most relevant predictor of a positive attitude to professional future and constructive professional development.

\section{REFERENCES}

Petrash, M. D. (2008). A subject of Activity Development in different period of adulthood. Psychology, Sociology, Pedagogy, 12(4), 103-110.

Petrash M.D. (2011). Psychological content and factors of incipient professional-development crisis at the early stages of professional activity. Experimental Psychology, 4, 88-100. 